\title{
Antioxidant Properties of Four Commonly Consumed Popular Italian Dishes
}

\author{
Alessandra Durazzo ${ }^{1, *}$, Massimo Lucarini ${ }^{1, *}$, Antonello Santini ${ }^{2}{ }^{(\mathbb{C}}$, Emanuela Camilli ${ }^{1}{ }^{(0}$, \\ Paolo Gabrielli ${ }^{1}$, Stefania Marconi ${ }^{1}$, Silvia Lisciani ${ }^{1} \mathbb{D}$, Altero Aguzzi ${ }^{1}$, Loretta Gambelli ${ }^{1}$, \\ Ettore Novellino $^{2}$ and Luisa Marletta ${ }^{1}$ (D) \\ 1 CREA Research Centre for Food and Nutrition, Via Ardeatina 546, 00178 Rome, Italy; \\ emanuela.camilli@crea.gov.it (E.C.); paolo.gabrielli@crea.gov.it (P.G.); stefania.marconi@crea.gov.it (S.M.); \\ silvia.lisciani@crea.gov.it (S.L.); altero.aguzzi@crea.gov.it (A.A.); loretta.gambelli@crea.gov.it (L.G.); \\ luisa.marletta@crea.gov.it (L.M.) \\ 2 Department of Pharmacy, University of Napoli Federico II, Via D. Montesano 49, 80131 Napoli, Italy; \\ asantini@unina.it (A.S.); ettore.novellino@unina.it (E.N.) \\ * Correspondence: alessandra.durazzo@crea.gov.it (A.D.); massimo.lucarini@crea.gov.it (M.L.); \\ Tel.: +30-065-149-4430 (A.D.); +30-065-149-4446 (M.L.)
}

Received: 11 March 2019; Accepted: 16 April 2019; Published: 19 April 2019

\begin{abstract}
Four popular dishes belonging to Italian cuisine and widely consumed in the country were experimentally prepared in a dedicated lab-kitchen following a validated and standardized protocol. This study provides their antioxidant properties evaluating the contribution of extractable and non-extractable bioactive compounds, and identifying the assessment of interactions between their natural active compounds and the food matrix. Ferric reducing antioxidant power (FRAP) values in aqueous-organic extract ranged from the highest antioxidant activity in torta di mele $(10.72 \mu \mathrm{mol} / \mathrm{g}$ d.m.) to that in besciamella $(2.47 \mu \mathrm{mol} / \mathrm{g} \mathrm{d} . \mathrm{m}$.); in residue, pasta alla carbonara reached the highest value (73.83 $\mu \mathrm{mol} / \mathrm{g} \mathrm{d}$.m.) following by that in pasta alla amatriciana $(68.64 \mu \mathrm{mol} / \mathrm{g} \mathrm{d} . \mathrm{m}$.$) . Total polyphenol$ content (TPC) ranged in aqueous-organic extracts between 36.50 and $64.28 \mathrm{mg} / 100 \mathrm{~g} \mathrm{~d} . \mathrm{m}$. and in residue from 425.84 to $1747.35 \mathrm{mg} / 100 \mathrm{~g}$ d.m. Our findings may contribute to the updating of the Italian Food Composition Database, by providing for the first time a value for the antioxidant properties. This could contribute to encourage the consumption of recipes rich in key nutrients and bioactive molecules. This information is useful and important for determining the association between diet and a healthy status.
\end{abstract}

Keywords: Italian popular recipes; food composition database; antioxidant properties; extractable compounds; non-extractable compounds; ferric reducing antioxidant power (FRAP); total polyphenol content (TPC)

\section{Introduction}

The study of food bioactivity and epidemiological investigations are increasing, emphasizing the perspective of considering the whole food matrix of interest for the risk of disease onset. Following the evolution of nutrition science, currently, researchers are trying to identify the concept of "optimal nutrition" also by studying not only the characteristics and functions of the individual foods or food components, but also their combination in composite foods, dishes, meals, and diets, in order to understand their overall impact on health.

There are only a few foods which are consumed raw, mainly vegetables and fruit, while most foods are heat-treated using different methods chosen according to the matrix, the type of food preparation, and the recipe to prepare them. This aspect is affected by various cultures and culinary traditions. 
Cooked foods and composed dishes are in fact the most consumed in our daily diet, but there is still little information concerning them, both in terms of their nutritional characteristics and their potential functions, whereas numerous data are available in the literature on the single ingredients, without taking into account either the formulation or the effects of technological process [1]. The interactions between single food components and/or between the different ingredients of a composite dish can play an important role, amplifying the importance of the concept of "food synergy" on health [2]; studies on technological and cooking treatments during the preparation of a recipe also highlight how they can influence their total characteristics, influencing and reflecting the state of health and well-being of consumers. It is well known that the physical, organoleptic, and chemical changes produced in food by heat treatments influence different parameters such as sensorial characteristics, nutrients content, quality and availability, bioactivity, and phytochemical composition [3-6].

To accurately estimate the dietary intake of the population and prevent cardiovascular disease, cancer, diabetes, etc., in recent years, the focus has increasingly been on studying the nutritional characteristics of foods and traditional recipes that are ready for consumption [7-13], also with the purpose of formulating dietary recommendations $[14,15]$. This seems to suggest that there is a need to have comprehensive datasets and databases that include composite and processed foods and food preparations as well as accurate dietary information to investigate the links between diet and health. Currently available data are still limited for two reasons: the scarcity of information on the nutritional composition of commonly consumed foods, in particular processed foods and composite dishes [16], and the deficit of up-to-date knowledge about population dietary habits in different contexts. Food composition databases (FCDBs) are used as the main tool to assess the dietary intake of individuals and groups of people at the regional, national, and international levels [17-20]. In addition to providing dietary information, consumed food characteristics and their overall nutritional role are also addressed to preserve important cultural elements, such as the great variety of traditional Italian cuisine that distinguishes the gastronomy of the country and reflects both the history and the local characteristics [21].

Specific research projects, such as the European Food Information Resource (EuroFIR) network [22] and the Italian national project Food Quality and Functional (QUALIFU) [23], were created and developed precisely to study, protect, and maintain the significant culture and culinary traditions of a country; Italy, particularly rich with various traditional foods and dishes, has taken part in these projects, and several national traditional recipes widely consumed have been studied, since they play an important role in preserving the local and regional food cultures.

In this framework, the aim of the present work is to provide new information on the antioxidant properties of some Italian recipes with respect to a previous work [12], in terms of extractable and non-extractable compounds, to examine any healthy aspects and identify their potential beneficial role.

The total antioxidant properties contribute to an assessment of interactions between natural active compounds and other food matrix components of foods, and this can be considered as a first step and as preliminary action towards the comprehension of potential beneficial properties of food matrices from the perspective of healthy food choices [24]. Each food matrix has its own antioxidant capacity that derives from the combined action of carotenoids, lignans, polyphenols, vitamins $C$ and E, etc. Natural antioxidants can show different physiological properties, such as anti-inflammatory, antimicrobial, anti-allergic, anti-atherogenic, anti-thrombotic, cardio-protective, and vasodilatory effects [24-33]. With respect to antioxidant chemicals, it is worth mentioning that the current review of Yeung et al. [34], based on a scientific literature landscape analysis of works since 1991, concluded that a transition of the scientific interest, shifting from research focused on antioxidant vitamins and minerals to research on antioxidant phytochemicals (plant secondary metabolites), has been observed. In particular, the scientific community recently reached consensus on the distinction between extractable and non-extractable antioxidants: a development and assessment of methodologies was achieved [35]. Antioxidants occur in two forms [35,36]: as easily extractable compounds -free forms that are soluble in aqueous-organic solvents- and as less extractable compounds -bound forms that 
remain in the residue of aqueous-organic extract-. Their incidence in foodstuffs as raw, cooked, and processed food products was studied [37-48]. As remarked previously by Durazzo [35], due to the presence of multiple aspects and factors, it has become difficult to carry out a categorization of the main trends of the contribution of extractable and non-extractable compounds to the total antioxidant properties of major food groups. Generally, it is thought that the analysis of antioxidants in plant foods that remain in residues is necessary. Particular attention in fact should be paid to high fat food matrices [49] and to complex food matrices [12].

The assessment of bioactive compounds to dietary intake is a key issue. Additionally, a proper assessment of the contribution of extractable and non-extractable compounds to the dietary intake is required. Most of the studies available in the literature present daily intakes of extractable polyphenols, whereas little research has been done on the intake of non-extractable polyphenols [50-54], an important fraction contributing to total polyphenol intake [55]. Saura-Calixto et al. [50] estimated the amount of total polyphenols (as extractable and non-extractable polyphenols) consumed in a whole diet (Spanish Mediterranean diet) and their intestinal bioaccessibility: the amount of non-extractable polyphenols was almost double compared to extractable polyphenols. Pérez-Jiménez and Saura-Calixto [51] evaluated non-extractable polyphenols for the 24 most consumed fruit and vegetables in four European countries (France, Germany, The Netherlands, and Spain): macromolecular antioxidants, made up of hydrolysable polyphenols and polymeric proanthocyanidins, are the major contributors (mean value $57 \%$ ) to the total polyphenol content of fruit and vegetables, and the intake of non-extractable polyphenols was estimated at about $200 \mathrm{mg}$. In particular, the authors reported that Spain had the highest daily per capita non-extractable polyphenols intake from fruit, whereas the Netherlands had the highest intake derived from vegetable consumption [51]. It is worth mentioning the work of Koehnlein et al. [52] on estimation of the total dietary antioxidant capacity (TDAC) in the Brazilian population: TDAC, evaluated as the ferric-reducing antioxidant power and as the Trolox equivalent antioxidant capacity, was 10.3 and $9.4 \mathrm{mmol} / \mathrm{d}$, respectively. In a further work [53], the same authors compared the phenolic content and the total antioxidant capacity of the 36 most popular Brazilian foods submitted to aqueous extraction or in vitro digestion: after in vitro digestion, cereals, legumes, vegetables, tuberous vegetables, chocolate, and fruits showed higher phenolic contents and higher antioxidant activities than those obtained by aqueous extraction. The digestion caused a reduction in phenolic contents and the antioxidant activities of beverages (red wine, coffee, and yerba mate) [53]. Another work to mention is the research of Faller et al. [54] on the chemical and cellular antioxidant activity of feijoada, a typical Brazilian dish, coupled with an in vitro digestion: bound and residue contributions to total phenolics were $20.9 \%$ and $32.2 \%$, respectively, suggesting that phenolics are capable of reaching the colon after the intake.

The overall goal is the development of specified and dedicated databases as well as the inclusion of extractable and non-extractable compounds in current comprehensive and harmonized FCDBs for a better and correct dietary intake assessment. Studies direction $[56,57]$ on this are carried out in eBASIS BioActive Substances in Food Information System [58-60]: search protocols and data collection systems are developed to enable the expansion of eBASIS with new quality evaluated data on extractable and non-extractable antioxidants, producing a valuable unique resource [56,57].

The present study evaluates the contribution of extractable and non-extractable bioactive compounds on the antioxidant properties of four popular Italian dishes commonly consumed, previously characterized by their nutrient content [13], to better understand their nutritional role and provide additional dietary information to be included in the next update of the Italian National Food Composition Database (FCDB) of the CREA Research Centre for Food and Nutrition.

\section{Results and Discussion}

In our study, the antioxidant properties of the whole matrix as consumed were studied due to the complexity of the examined matrices. The changes in antioxidants and the interactions between 
components are correlated to the phytochemical structure and concentration, to the typology of food matrixes, to the preparation procedure, and to the typology and time of cooking [61-64].

In Table 1, Ferric Reducing Antioxidant Power (FRAP) values ( $\mu \mathrm{mol} / \mathrm{g} \mathrm{d.m.)} \mathrm{and} \mathrm{Total} \mathrm{Polyphenol}$ Content (TPC) (mg/100 g d.m.) were reported for selected popular Italian dishes.

Table 1. Ferric Reducing Antioxidant Power (FRAP) and Total Polyphenol Content (TPC) of popular Italian dishes *.

\begin{tabular}{ccccc}
\hline & \multicolumn{2}{c}{ FRAP $(\mu \mathrm{mol} / \mathbf{g}$ d.m.) } & \multicolumn{2}{c}{ TPC (mg/100 g d.m.) } \\
\cline { 2 - 5 } & Aqueous-Organic Extract & Residue & Aqueous-Organic Extract & Residue \\
\hline Pasta alla & $4.01 \pm 0.67^{\mathrm{b}}$ & $68.64 \pm 4.43^{\mathrm{c}}$ & $60.87 \pm 5.48^{\mathrm{c}}$ & $1447.59 \pm 70.33^{\mathrm{c}}$ \\
$\begin{array}{c}\text { amatriciana } \\
\text { Pasta alla carbonara }\end{array}$ & $2.62 \pm 0.53^{\mathrm{a}}$ & $73.83 \pm 3.52^{\mathrm{d}}$ & $36.50 \pm 6.31^{\mathrm{a}}$ & $1747.35 \pm 72.91^{\mathrm{d}}$ \\
Besciamella & $2.47 \pm 0.17^{\mathrm{a}}$ & $52.98 \pm 1.22^{\mathrm{b}}$ & $51.90 \pm 3.38^{\mathrm{b}}$ & $1173.44 \pm 73.07^{\mathrm{b}}$ \\
Torta di mele & $10.72 \pm 0.80^{\mathrm{c}}$ & $18.24 \pm 5.09^{\mathrm{a}}$ & $64.28^{\mathrm{a}} \pm 2.39^{\mathrm{c}}$ & $425.84 \pm 63.86^{\mathrm{a}}$ \\
\hline
\end{tabular}

* Mean \pm S.D.; ANOVA and Tukey's HSD test: by column, means followed by different letters are significantly different $(p<0.05)$.

FRAP values in aqueous-organic extract decreased in the following order: torta di mele > pasta alla amatriciana > pasta alla carbonara = besciamella; in residue, pasta alla carbonara reached the highest value followed by pasta alla amatriciana. The FRAP values of pasta-based dishes confirmed the value reported in our previous work [12] for another dish, the spaghetti alle vongole, namely $4.20 \mu \mathrm{mol} / \mathrm{g} \mathrm{d} . \mathrm{m}$. and $64.22 \mu \mathrm{mol} / \mathrm{g}$ d.m. in aqueous-organic extract and residue, respectively. In general, the antioxidant properties of cereals and derivatives thereof have been well documented over the years $[42,65,66]$; with reference to antioxidants in pasta, one of most popular staple foods, the effect of cooking $[67,68]$ as well as new formulations and functional products have been studied [69-72]. In this regard, it is worth mentioning the work of Ioannou et al. [63], since they remarked how the addition of ingredients with high antioxidant activity to a complex preparation can contribute to increases in total antioxidant capacity, but not in a proportional way.

Besciamella belongs to the category of the white sauces, and it is an example of milk-based dishes. In recent years, emerging studies on the antioxidant properties of milk [73,74] as well as dairy products [75,76] have been carried out. For instance, Manzi and Durazzo [74], by evaluating the antioxidant properties of industrial heat-treated milk, namely UHT, microfiltered, and high quality pasteurized milk, showed that UHT milk has the highest total polyphenol content, DPPH, and FRAP values. The authors [74] explained that the behavior of UHT milk is probably related to the development of antioxidant compounds, formed during the Maillard reaction occurring when milk treatment is performed at high temperatures $\left(\geq 135^{\circ} \mathrm{C}\right.$ for at least $\left.1 \mathrm{~s}\right)$ according to previous authors [77-79].

Torta di mele belongs to the subcategory of fruit cake comprised among the desserts, and evidenced the highest FRAP value in aqueous-organic extract and the lowest value in the residue with respect to other items. This seems to reflect the high content of organic acids in the apples used in the preparation of this dessert [80,81]. For instance, for apple, in Phenol Explorer Databases the total polyphenol content was $131.80 \mathrm{mg} / 100 \mathrm{~g} \mathrm{FW}$, as mean of 53 original content values extracted from eight published papers [82].

Table 2 shows and summarizes the contribution of extractable and non-extractable compounds to the antioxidant properties of all Italian dishes we investigated grouped by category, in this work and in a previous one [12].

For the four new dishes studied, the extractable antioxidants (aqueous-organic extracts) were minor contributors to the total antioxidant activity; consequently, the hydrolysable polyphenols (residues) contributed significantly more: for pasta alla amatriciana, pasta alla carbonara, and besciamella the extractable antioxidants contribute less than $6 \%$ and non-extractable compounds contribute in a range from 94 to $97 \%$, whereas for torta di mele the percentages of contributions were $37 \%$ and $63 \%$, respectively, for extractable polyphenols and hydrolysable polyphenols. 
Table 2. Contribution \% of extractable and non-extractable compounds to antioxidant properties of popular Italian dishes *.

\begin{tabular}{ccc}
\hline Italian Dishes & Aqueous-Organic Extract & Residue \\
\hline Sauces & 4 & \\
Besciamella & & 96 \\
First Courses & 6 & 94 \\
Spaghetti alle vongole & 6 & 94 \\
Pasta alla amatriciana & 3 & 97 \\
Pasta alla carbonara & 15 & \\
One Dish Meals & 11 & 85 \\
Pomodori al riso * & & \\
Gâteau di patate * & 58 & 42 \\
Side Courses & & 95 \\
Carciofi alla romana * & 5 & 63 \\
Desserts & 37 & \\
Pan di Spagna * & & \\
Torta di mele & &
\end{tabular}

* Data derived from Durazzo et al. [12].

Regarding total polyphenol content evaluation, as reported in Table 1, TPC values ranged in aqueous-organic extracts between 36.50 and $64.28 \mathrm{mg} / 100 \mathrm{~g} \mathrm{~d}$.m. and in residue from 425.84 to $1747.35 \mathrm{mg} / 100 \mathrm{~g}$ d.m. Hydrolysable polyphenols represent consequently a significant fraction, by accounting in the range between $87 \%$ (torta di mele) and $98 \%$ (pasta alla carbonara) of total polyphenols. A good Pearson correlation between TPC values with FRAP ones was found in aqueous-organic extract $(\mathrm{r}=0.6798)$ and in residues $(\mathrm{r}=0.9909)$. For instance, pasta alla carbonara showed the lowest values in aqueous-organic extract and the highest value in residue both in FRAP and TPC, whereas torta di mele showed the opposite behavior.

\section{Materials and Methods}

\subsection{Recipes: Identification of Standard Recipe, Sampling and Dish Preparation}

Four recipes (Table 3), all identified from survey Italian National Food Consumption Survey INRAN-SCAI 2005-2006 [83], and selected in the QUALIFU project [23], were experimentally prepared [13] in a dedicated lab-kitchen following a validated and standardized protocol developed within the EuroFIR Network [84]; three preparations represented some popular, most commonly consumed Italian dishes: pasta alla amatriciana; pasta alla carbonara, and torta di mele; one sauce, the besciamelle, was selected and studied for its great use in other traditional food preparations (lasagna, vegetables au gratin, baked pasta, salted cakes, etc.). The different ingredients included were pasta, cured meat, milk, cheeses, eggs, vegetables, fruits, extra virgin olive oil, and butter, thus covering a wide range of antioxidant properties. Our previous studies on traditional Italian dishes were focused on determining proximate composition and a dietary intake evaluation $[12,13]$ and aimed at applying an integrated and emerging (analytical) approach to classifying dishes [85,86]. The present study focuses on the health-beneficial properties of selected traditional Italian dishes with the aim of extending and triggering interest to this type of research, which connects the nutritional aspects to health-beneficial properties and traditionally consumed foods. 
Table 3. Italian popular dishes: ingredients, method and time cooking.

\begin{tabular}{|c|c|c|c|c|}
\hline Original Name & Food Name & Ingredients $(\mathrm{g} / 100 \mathrm{~g})$ & Cooking & Timing (min.) \\
\hline $\begin{array}{l}\text { Pasta alla } \\
\text { amatriciana }\end{array}$ & Amatriciana pasta & $\begin{array}{l}\text { Short pasta (37.5), tomato pulp } \\
\text { (37.5), Amatrice cheek lard diced } \\
\text { (16), Amatrice Pecorino cheese } \\
\text { PAT (hard cheese from sheep) } \\
\text { (7.5), extra virgin olive oil (1.1), } \\
\text { salt (0.3), chili pepper (0.1). }\end{array}$ & $\begin{array}{l}\text { Boiling, pan-frying, } \\
\text { and simmering }\end{array}$ & 25 \\
\hline Pasta alla carbonara & Carbonara pasta & $\begin{array}{l}\text { Short pasta (47.3), bacon cubes } \\
\text { (20.3), Roman Pecorino cheese } \\
\text { PDO (hard cheese from sheep) } \\
\text { (13.6), eggs (16.6), extra virgin } \\
\text { olive oil (1.4), salt }(0.4) \text {, black } \\
\text { pepper }(0.4) .\end{array}$ & $\begin{array}{l}\text { Boiling and } \\
\text { pan-frying }\end{array}$ & 13 \\
\hline Besciamella & Béchamel sauce & $\begin{array}{l}\text { Milk (83), butter (8), flour (8), } \\
\text { salt (0.5). }\end{array}$ & Simmering gently & 33 \\
\hline Torta di mele & Apple Pie & $\begin{array}{l}\text { Apples (37.7), sugar (15), wheat } \\
\text { flour (18), butter (9.3), eggs }(9.2) \text {, } \\
\text { whole milk (7.5), baking powder } \\
\text { (1), vanilla (0.03), grated lemon } \\
\text { peel (0.2), lemon juice (2.4). }\end{array}$ & Baking & 30 \\
\hline
\end{tabular}

In detail, at first a document collection was carried out from the most popular and traditional cookbooks in Italy (Il cucchiaio d'argento; La cucina italiana, etc.) for every recipe selected; therefore, for every dish one "standard recipe" was identified and one "preparation protocol" was drafted in detail identifying ingredients, quantities, preparation techniques, type, temperature, and time cooking; dishes production had been carried out according to the standard procedures developed within the EuroFIR network.

The sampling plan had taken into account the collection of simple ingredients at various retail stores and supermarkets in Rome; to represent the variability of the ingredients, the main brands and cultivars of the same product were considered and purchased: 8 brands of pasta and tomato pulp, 7 brands of eggs, 6 brands of bacon, 4 samples of Amatrice cheek lard and Pecorino cheese, 4 brands of extra virgin olive oil, and 2 brands of wheat flour, butter, and milk. Each brand (primary sample) for every ingredient (secondary sample) was properly prepared, weighed, and then combined to make a composite sample (pool) before use for the preparation of the final dish (laboratory sample). This was weighed, assembled, and cooked in a laboratory and dedicated kitchen at the CREA Research Centre for Food and Nutrition by trained persons according to the preparation protocol of the standard recipe, applying methods and utensils commonly used in households. The recipes, once completed and cooked, were homogenized, frozen at $-30{ }^{\circ} \mathrm{C}$, and lyophilized. For each type of dish, two independent batches (laboratory sample) were prepared and on each one the analysis were performed in triplicate.

\subsection{Evaluation of Antioxidant Properties by Ferric Reducing Antioxidant Power (FRAP) and Total Polyphenol} Content (TPC)

\subsubsection{Extraction Procedure}

Extractable and non-extractable polyphenols were extracted as described by Durazzo et al. [12]. Aqueous-organic extracts (extractable antioxidants) and their residues (non-extractable antioxidants) were isolated and studied.

In particular, among non-extractable antioxidants, attention was paid to hydrolysable polyphenols, which were isolated and determined following a specific and suitable acid hydrolysis procedure as reported below. 


\section{Aqueous-Organic Extract}

On the basis of dish ingredients and available literature data, a quantity of 3-5.5 $\mathrm{g}$ of each sample was placed in a test tube, and $20 \mathrm{~mL}$ of acid methanol/water $(50: 50 v / v, \mathrm{pH} 2)$ were added. The tubes were vortexed at room temperature for $3 \mathrm{~min}$ and then mildly shaken for $1 \mathrm{~h}$ in a water bath at room temperature. The tubes were then centrifuged at $2500 \mathrm{rpm}$ for $10 \mathrm{~min}$ and the supernatants were recovered. Twenty milliliters of acetone/water $(70: 30 \mathrm{v} / \mathrm{v})$ mixture were added to the residues. All operations (vortexing, shaking, centrifugation) were then repeated. Methanolic and acetonic extracts were combined and centrifuged at $2800 \mathrm{rpm}$ for $15 \mathrm{~min}$. The resulting supernatant was transferred into tubes and directly used for the determination of FRAP and TPC.

Residue

The residues remaining after the previously described extraction were left in a ventilated and heated apparatus (max temperature $25^{\circ} \mathrm{C}$ ) until dry. Briefly, about $200-450 \mathrm{mg}$ of the residue, respectively, were mixed with $20 \mathrm{~mL}$ of methanol and $2 \mathrm{~mL}$ of concentrated sulfuric acid $(18 \mathrm{M})$. The samples were gently stirred for $1 \mathrm{~min}$ and were shaken in a water bath at $85^{\circ} \mathrm{C}$ for $20 \mathrm{~h}$; samples were then centrifuged ( $2500 \mathrm{~g}$ for $10 \mathrm{~min}$ ), and the supernatant was recovered. After two washings, with minimum volumes of distilled water and recentrifuging where necessary, the final volume was $50 \mathrm{~mL}$. The tube was centrifuged at $2800 \mathrm{rpm}$ for $20 \mathrm{~min}$, and the resultant supernatant was directly used for the determination of FRAP and TPC.

\subsubsection{Antioxidant Assays}

Several methods have been proposed for evaluating the antioxidant properties of single compounds and foods [87]. The most common are (i) the Folin-Ciocalteu assay used widely to determine the total phenolics; (ii) the Trolox equivalent antioxidant capacity (TEAC); (iii) the oxygen radical absorbance capacity (ORAC); (iv) the total radical-trapping antioxidant parameter (TRAP); (v) the ferric-reducing antioxidant power (FRAP); and (vi) the 2,2-diphenyl-1-picrylhydrazyl (DPPH) radical scavenging activity assay [88-90]. All these methods are based on the measurement of the capacity of a food component or a food to scavenge specific free radicals or to reduce a target molecule.

These assays differ in their principles, mechanisms, and experimental conditions as well as in how their end points are measured, so different methods to estimate and/or determine the antioxidant activity of the compounds should be carried out. Three are the main mechanisms by which the antioxidants act, encompassing the direct reaction with radicals and the chelation of free metals (involved in reaction finally generating free radicals): the $\mathrm{H}$ atom transfer, the single electron transfer, and the metal chelation [91]. Literature data report that the use of at least two or three assays is strongly recommended for assessing antioxidant properties [92]. Prior et al. [93] proposed that procedures and applications for three assays should be considered for standardization: the oxygen radical absorbance capacity (ORAC) assay, the Folin-Ciocalteu method, and possibly the Trolox equivalent antioxidant capacity (TEAC) assay [93].

\section{FRAP}

The determination of the FRAP assay was carried out according to the methods of Benzie \& Strain [94] and Pulido et al. [95], through the use of a Tecan Sunrise ${ }^{\circledR}$ plate reader spectrophotometer. The method is based on the reduction of the $\mathrm{Fe}^{3+-} \mathrm{TPTZ}$ (2,4,6-tripyridyl-s-triazine) complex to a ferrous one at acidic $\mathrm{pH}$ value.

\section{Total Polyphenol Content (TPC)}

The TPC was determined using the Folin-Ciocalteu method [96]. Briefly, appropriate dilutions of extracts were oxidized with Folin-Ciocalteu reagent, and the reaction was neutralized with sodium carbonate. The absorbance of the resulting blue color was measured at a wavelength of $760 \mathrm{~nm}$ 
against an appropriate blank after $2 \mathrm{~h}$ of reaction at room temperature. Gallic acid was used as reference standard.

\subsection{Statistical Analysis}

All analyses were performed in triplicate. Data are presented as mean \pm standard deviation (s.d.) of the analysis carried out on two preparations of every dish. Statistica for Windows (Statistical package; release 4.5; StatSoft Inc., Vigonza, PD, Italy) was used to perform one-way analysis of variance (ANOVA) and a post-hoc test: Tukey's honest significant difference (HSD) test.

\section{Conclusions}

In this study, antioxidant properties of four commonly consumed popular Italian dishes are provided for the first time. Our findings can contribute to the updating of the Italian FCDB by providing a value of antioxidant properties that are useful and important for study on the association between diet and a healthy status $[97,98]$.

The innovative character of this research lays in the fact that the four dishes were experimentally prepared in a dedicated lab-kitchen following a validated and standardized protocol based on harmonized guidelines. The other key aspect is the study of antioxidant properties, in term of extractable and non-extractable antioxidants, applied to complex matrixes, i.e., food preparations and food composite dishes.

Our study highlighted the importance of evaluating the real nutritional information about foods as taken, since ingredients are often mixed and heat-treated to formulate/prepare dishes. The availability of these new and appropriate food composition data is needed in order to correctly evaluate the dietary intake of recipes rich in key nutrients and bioactive molecules, facilitating further nutrition-related studies, and can be used to encourage the consumption of certain recipes. Further studies in this direction are needed to provide a detailed nutritional overview of popular and traditional Italian dishes and are currently being carried out in our laboratories.

Author Contributions: A.D., M.L., A.S., E.N. and L.M. have conceived the work and wrote the manuscript. P.G., S.M., S.L., A.A., and L.G. have carried out the experimental study and A.D., M.L., A.S., E.C., E.N. and L.M. analyzed the data. All authors have made a substantial contribution to revise the work and approved it for publication.

Funding: This work was supported by the project QUALIFU-SIAGRO (MiPAAF D.M. 2087/7303/09, 28/01/2009).

Conflicts of Interest: The authors declare no conflict of interest.

\section{References}

1. Pennington, L. Food composition database for bioactive food components. J. Food Compos. Anal. 2002, 15, 419-434. [CrossRef]

2. Jacobs, D.R.; Tapsell, L.C. Food, not nutrients, is the fundamental unit in nutrition. Nutr. Rev. 2007, 65, 439-450. [CrossRef] [PubMed]

3. Naviglio, D.; Romano, R.; Pizzolongo, F.; Santini, A.; De Vivo, A.; Schiavo, L.; Nota, G.; Spagna Musso, S. Rapid determination of esterified glycerol and glycerides in triglycerides fats and oils by means of periodate method after transesterification. Food Chem. 2007, 102, 399-405. [CrossRef]

4. Pannico, A.; Schouten, R.E.; Basile, B.; Romano, R.; Woltering, E.J.; Cirillo, C. Non-destructive detection of flawed hazelnut kernels and lipid oxidation assessment using NIR spectroscopy. J. Food Eng. 2015, 160, 42-48. [CrossRef]

5. Cilla, A.; Bosch, L.; Barberá, R.; Alegría, A. Effect of processing on the bioaccessibility of bioactive compounds-A review focusing on carotenoids, minerals, ascorbic acid, tocopherols and polyphenols. J. Food Compos. Anal. 2018, 68, 3-15. [CrossRef]

6. Romano, R.; Giordano, A.; Le Grottaglie, L.; Manzo, N.; Paduano, A.; Sacchi, R.; Santini, A. Volatile compounds in intermittent frying by gas chromatography and nuclear magnetic resonance. Eur. J. Lipid Sci. Technol. 2013, 115, 764-773. [CrossRef] 
7. D’Evoli, L.; Salvatore, P.; Lucarini, M.; Nicoli, S.; Aguzzi, A.; Gabrielli, P.; Lombardi-Boccia, G. Nutritional value of traditional Italian meat-based dishes: Influence of cooking methods and recipe formulation. Int. J. Food Sci. Nutr. 2009, 60, 38-49. [CrossRef]

8. Marletta, L.; Camilli, E.; Turrini, A.; Scardella, P.; Spada, R.; Piombo, L.; Khokhar, S.; Finglas, P.; Carnovale, E. The nutritional composition of selected ethnic foods consumed in Italy. Nutr. Bull. 2010, 35, 350-356. [CrossRef]

9. Lucarini, M.; D’Evoli, L.; Nicoli, S.; Aguzzi, A.; Gabrielli, P.; Lombardi-Boccia, G. Effect of cooking treatments on nutrient profile of dishes based on veal meat. Italian J. Food Sci. 2011, 23, 395-403.

10. Ramdath, D.D.; Hilaire, D.G.; Brambilla, A.; Sharma, S. Nutritional composition of commonly consumed composite dishes in Trinidad. Int. J. Food Sci. Nutr. 2011, 62, 34-46. [CrossRef]

11. Costa, H.S.; Albuquerque, T.G.; Sanches-Silva, A.; Vasilopoulou, E.; Trichopoulou, A.; D'Antuono, L.F.; Alexieva, I.; Boyko, N.; Costea, C.; Fedosova, K.; et al. New nutritional composition data on selected traditional foods consumed in Black Sea Area countries. J. Sci. Food Agric. 2013, 93, 3524-3534. [CrossRef]

12. Durazzo, A.; Lisciani, S.; Camilli, E.; Gabrielli, P.; Marconi, S.; Gambelli, L.; Aguzzi, A.; Lucarini, M.; Maiani, G.; Casale, G.; et al. Nutritional composition and antioxidant properties of traditional Italian dishes. Food Chem. 2017, 218, 70-77. [CrossRef] [PubMed]

13. Durazzo, A.; Camilli, E.; Marconi, S.; Lisciani, S.; Gabrielli, P.; Gambelli, L.; Aguzzi, A.; Lucarini, M.; Kiefer, J.; Marletta, L. Nutritional composition and dietary intake of composite dishes traditionally consumed in Italy. J. Food Compos. Anal. 2019, 77, 115-124. [CrossRef]

14. SINU, Società Italiana di Nutrizione Umana. Livelli di Assunzione di Riferimento di Nutrienti ed Energia per la Popolazione Italiana; (IV Revisione); SICS (Società Italiana di Comunicazione Scientifica e Sanitaria): Milano, Italy, 2014.

15. Finglas, P.; Roe, M.; Pinchen, H.; Astley, S. The contribution of food composition resources to nutrition science methodology. Br. Nutr. Found. Nutr. Bull. 2017, 42, 198-206. [CrossRef]

16. Ribeiro, P.; de Moris, T.B.; Colugnati, F.A.; Sigulem, D.M. Food composition tables: Laboratory comparative analysis. Revista de Saude Publica 2003, 37, 216-225. [CrossRef]

17. Gibson, R.S. Principles of Nutritional Assessment, 2nd ed.; Oxford University Press: New York, NY, USA, 2005.

18. Elmadfa, I.; Meyer, A.L. Importance of food composition data to nutrition and public health. Eur. J. Clin. Nutr. 2010, 3, 4-7. [CrossRef]

19. Church, S.M. The importance of food composition data in recipe analysis. Nutr. Bull. 2015, 40, 40-44. [CrossRef]

20. Howie, M. The nutritional value of food: A retailer's view on McCance and Widdowson's The Composition of Foods Data. Br. Nutr. Found. Nutr. Bull. 2015, 40, 104-106. [CrossRef]

21. Capatti, A.; Montanari, M. La cucina italiana. In Storia di una Cultura, 7th ed.; Laterza: Bari, Italy, 2006.

22. EuroFIR AISBL. EuroFIR—European Food Information Resource. Available online: http://www.eurofir.org (accessed on 10 January 2019).

23. Project Food Quality and Functional (QUALIFU). Available online: http://nut.entecra.it/441/qualita alimentare_e_funzionale_qualifu.html (accessed on 10 January 2019).

24. Durazzo, A.; Lucarini, M. A Current shot and re-thinking of antioxidant research strategy. Braz. J. Anal. Chem. 2018, 5, 9-11. [CrossRef]

25. Andrew, R.; Izzo, A.A. Principles of pharmacological research of nutraceuticals. Br. J. Pharmacol. 2017, 174, 1177-1194. [CrossRef]

26. Santini, A.; Novellino, E.; Armini, V.; Ritieni, A. State of the art of Ready-to-Use Therapeutic Food: A tool for nutraceuticals addition to foodstuff. Food Chem. 2013, 140, 843-849. [CrossRef] [PubMed]

27. Santini, A.; Novellino, E. To Nutraceuticals and Back: Rethinking a Concept. Foods 2017, 6, 74. [CrossRef]

28. Santini, A.; Tenore, G.C.; Novellino, E. Nutraceuticals: A paradigm of proactive medicine. Eur. J. Pharm. Sci. 2017, 96, 53-61. [CrossRef] [PubMed]

29. Santini, A.; Novellino, E. Nutraceuticals: Shedding light on the grey area between pharmaceuticals and food. Expert Rev. Clin. Pharmacol. 2018, 11, 545-547. [CrossRef]

30. Santini, A.; Cammarata, S.M.; Capone, G.; Ianaro, A.; Tenore, G.C.; Pani, L.; Novellino, E. Nutraceuticals: Opening the debate for a regulatory framework. Br. J. Clin. Pharmacol. 2018, 84, 659-672. [CrossRef]

31. Daliu, P.; Santini, A.; Novellino, E. From pharmaceuticals to nutraceuticals: Bridging disease prevention and management. Expert Rev. Clin. Pharmacol. 2018, 28, 1-7. [CrossRef] [PubMed] 
32. Daliu, P.; Santini, A.; Novellino, E. A decade of nutraceutical patents: Where are we now in 2018? Expert Opin. Ther. Patents 2018, 28, 875-882. [CrossRef] [PubMed]

33. Durazzo, A.; D'Addezio, L.; Camilli, E.; Piccinelli, R.; Turrini, A.; Marletta, L.; Marconi, S.; Lucarini, M.; Lisciani, S.; Gabrielli, P.; et al. From Plant Compounds to Botanicals and Back: A Current Snapshot. Molecules 2018, 23, 1844. [CrossRef]

34. Yeung, A.W.K.; Tzvetkov, N.T.; El-Tawil, O.S.; Bungǎu, S.G.; Abdel-Daim, M.M.; Atanasov, A.G. Antioxidants: Scientific Literature Landscape Analysis. Oxid. Med. Cell. Longev. 2019, 2019, 8278454. [CrossRef]

35. Durazzo, A. Study Approach of Antioxidant Properties in Foods: Update and Considerations. Foods 2017, 6, 17. [CrossRef]

36. Durazzo, A. Extractable and Non-extractable polyphenols: An overview. In Non-Extractable Polyphenols and Carotenoids: Importance in Human Nutrition and Health; Saura-Calixto, F., Pérez-Jiménez, J., Eds.; Royal Society of Chemistry: London, UK, 2018; pp. 1-37.

37. Ebun, O.; Santosh, K. Effect of domestic cooking on the polyphenolic content and antioxidant capacity of plantain (Musa paradisiaca). World J. Dairy Food Sci. 2011, 6, 189-194.

38. Pérez-Jiménez, J.; Torres, J.L. Analysis of non-extractable phenolic compounds in foods: The current state of the art. J. Agric. Food Chem. 2011, 59, 12713-12724. [CrossRef] [PubMed]

39. Durazzo, A.; Turfani, V.; Azzini, E.; Maiani, G.; Carcea, M. Phenols, lignans and antioxidant properties of legume and sweet chestnut flours. Food Chem. 2013, 140, 666-671. [CrossRef] [PubMed]

40. Durazzo, A.; Turfani, V.; Narducci, V.; Azzini, E.; Maiani, G.; Carcea, M. Nutritional characterisation and bioactive components of commercial carobs flours. Food Chem. 2014, 153, 109-113. [CrossRef]

41. Pérez-Jiménez, J.; Díaz-Rubio, M.E.; Saura-Calixto, F. Non-extractable polyphenols, a major dietary antioxidant: Occurrence, metabolic fate and health effects. Nutr. Res. Rev. 2013, 26, 118-129. [CrossRef] [PubMed]

42. Camelo-Méndez, G.A.; Bello-Pérez, L.A. Antioxidant Capacity of Extractable and Non-extractable Polyphenols of Pigmented Maize. Food Biotechnol. 2014, 4, 6-13.

43. Durazzo, A.; Gabrielli, P.; Manzi, P. Qualitative Study of Functional Groups and Antioxidant Properties of Soy-Based Beverages Compared to Cow Milk. Antioxidants 2015, 4, 523-532. [CrossRef]

44. Zambrano-Moreno, E.L.; Chávez-Jáuregui, R.N.; de Lurdes, P.M.; Wessel-Beaver, L. Phenolic content and antioxidant capacity in organically and conventionally grown eggplant (Solanum melongena) fruits following thermal processing. Food Sci. Technol. 2015, 35, 414-420. [CrossRef]

45. Olivas-Aguirre, F.J.; González-Aguilar, G.A.; Velderrain-Rodríguez, G.R.; Torres-Moreno, H.; Robles-Zepeda, R.E.; Vázquez-Flores, A.A.; de la Rosa, L.A.; Wall-Medrano, A. Radical scavenging and anti-proliferative capacity of three freeze-dried tropical fruits. Int. J. Food Sci. Technol. 2017, 52, 1699-1709. [CrossRef]

46. Peng, H.; Li, W.; Li, H.; Deng, Z.; Zhang, B. Extractable and nonextractable bound phenolic compositions and their antioxidant properties in seed coat and cotyledon of black soybean (Glycinemax (L.) Merr). J. Funct. Foods 2017, 32, 296-312. [CrossRef]

47. Sanz-Pintos, N.; Pérez-Jiménez, J.; Buschmann, A.H.; Vergara-Salinas, J.R.; Pérez-Correa, J.R.; Saura-Calixto, F. Macromolecular Antioxidants and Dietary Fiber in Edible Seaweeds. J. Food Sci. 2017, 82, 289-295. [CrossRef]

48. Song, Y.; Wei, X.Q.; Li, M.Y.; Duan, X.W.; Sun, Y.M.; Yang, R.L.; Su, X.D.; Huang, R.M.; Wang, H. Nutritional Composition and Antioxidant Properties of the Fruits of a Chinese Wild Passiflora foetida. Molecules 2018, 23, 459. [CrossRef] [PubMed]

49. Arranz, S.; Perez-Jimenez, J.; Saura-Calixto, F. Antioxidant capacity of walnut (Juglans regia L.): Contribution of oil and defatted matter. Eur. Food Res. Technol. 2008, 227, 425-431. [CrossRef]

50. Saura-Calixto, F.; Serrano, J.; Goni, I. Intake and Bioaccessibility of Total Polyphenols in a Whole Diet. Food Chem. 2007, 101, 492-501. [CrossRef]

51. Pérez-Jiménez, J.; Saura-Calixto, F. Macromolecular antioxidants or non-extractable polyphenols in fruit and vegetables: Intake in four European countries. Food Res. Int. 2015, 74, 315-323. [CrossRef]

52. Koehnlein, E.A.; Bracht, A.; Nishida, V.S.; Peralta, R.M. Total antioxidant capacity and phenolic content of the Brazilian diet: A real scenario. Int. J. Food Sci. Nutr. 2014, 65, 293-298. [CrossRef] [PubMed]

53. Koehnlein, E.A.; Koehnlein, É.M.; Corrêa, R.C.; Nishida, V.S.; Correa, V.G.; Bracht, A.; Peralta, R.M. Analysis of a whole diet in terms of phenolic content and antioxidant capacity: Effects of a simulated gastrointestinal digestion. Int. J. Food Sci. Nutr. 2016, 67, 614-623. [CrossRef] [PubMed] 
54. Faller, A.L.K.; Fialho, E.; Liu, R.H. Cellular Antioxidant Activity of Feijoada Whole Meal Coupled with an in Vitro Digestion. J. Agric. Food. Chem. 2012, 60, 4826-4832. [CrossRef] [PubMed]

55. Pinto, P.; Santo, C.N. Worldwide (poly)phenol intake: Assessment methods and identified gaps. Eur. J. Nutr. 2017, 56, 1393-1408. [CrossRef] [PubMed]

56. Durazzo, A.; Plumb, J.; Lucarini, M.; Fernandez-Lopez, G.; Camilli, E.; Turrini, A.; Finglas, P.; Marletta, L. Extractable and Non-Extractable Antioxidants at the Interface of eBASIS Structure: Database Development and Expansion; EuroFIR Food Forum: Brussels, Belgium, 2018.

57. Plumb, J.; Fernandez-Lopez, G.; Durazzo, A.; Lucarini, M.; Mantur-Vierendeel, A.; Camilli, E.; Turrini, A.; Marletta, L.; Finglas, P. Compiling quality evaluated data on extractable and non-extractable antioxidants within the eBASIS database Bioavailability 2018 Conference, 10-13 September, Nowich. In Proceedings of the Bioavailability 2018, Norwich, UK, 10-13 September 2018.

58. eBASIS-Bioactive Substances in Food Information System. Available online: http://ebasis.eurofir.org/ Default.asp (accessed on 8 January 2019).

59. Kiely, M.; Black, L.J.; Plumb, J.; Kroon, P.A.; Hollman, P.C.; Larsen, J.C.; Speijers, G.J.; Kapsokefalou, M.; Sheehan, D.; Gry, J.; et al. EuroFIR eBASIS: Application for health claims submissions and evaluations. Eur. J. Clin. Nutr. 2010, 64, S101-S107. [CrossRef] [PubMed]

60. Plumb, J.; Pigat, S.; Bompola, F.; Cushen, M.; Pinchen, H.; Nørby, E.; Astley, S.; Lyons, J.; Kiely, M.; Finglas, P. eBASIS (Bioactive Substances in Food Information Systems) and bioactive intakes: Major updates of the bioactive compound composition and beneficial bio effects database and the development of a probabilistic model to assess intakes in Europe. Nutrients 2017, 9, 320. [CrossRef]

61. Manzocco, L.; Calligaris, S.; Mastrocola, D.; Nicoli, M.C.; Lerici, C.R. Review of non-enzymatic browning and antioxidant capacity in processed foods. Trends Food Sci. Technol. 2001, 11, 340-346. [CrossRef]

62. Pinelo, M.; Manzocco, L.; Nunez, M.J.; Nicoli, M.C. Interaction among phenols in food fortification: Negative synergism on antioxidant capacity. J. Agric. Food Chem. 2004, 52, 1177-1180. [CrossRef]

63. Ioannou, I. Comparative study of antioxidant activity between basic and convenience foods. J. Food Res. 2012, 1, 143-156. [CrossRef]

64. Amarowicz, R.; Carle, R.; Dongowski, G.; Durazzo, A.; Galensa, R.; Kammerer, D.; Maiani, G.; Piskula, M.K. Influence of postharvest processing and storage on the content of phenolic acids and flavonoids in foods. Mol. Nutr. Food Res. 2009, 53, S151-S183. [CrossRef]

65. Durazzo, A.; Casale, G.; Melini, V.; Maiani, G.; Acquistucci, R. Total polyphenol content and antioxidant properties of Solina (Triticum aestivum L.) and derivatives thereof. J. Food Sci. 2016, 28, 221.

66. Turfani, V.; Narducci, V.; Durazzo, A.; Galli, V.; Carcea, M. Technological, nutritional and functional properties of wheat bread enriched with lentil or carob flours. LWT-Food Sci. Technol. 2017, 78, 361. [CrossRef]

67. Hirawan, R.; Ser, W.Y.; Arntfield, S.D.; Beta, T. Antioxidant properties of commercial, regular- and wholewheat spaghetti. Food Chem. 2009, 119, 258-264. [CrossRef]

68. Durazzo, A.; Turfani, V.; Azzini, E.; Maiani, G.; Carcea, M. Antioxidant properties of experimental pastas made with different wholegrain cereals. J. Food Res. 2014, 3. [CrossRef]

69. Sant'Anna, V.; Christiano, F.D.P.; Marczak, L.D.F.; Tessaro, I.C.; Thys, R.C.S. The effect of the incorporation of grape marc powder in fettuccini pasta properties. LWT-Food Sci. Technol. 2014, 58, 497-501. [CrossRef]

70. Gull, A.; Prasad, K.; Kumar, P. Nutritional, antioxidant, microstructural and pasting properties of functional pasta. J. Saudi Soc. Agric. Sci. 2018, 17, 147-153. [CrossRef]

71. Ivanišováeva, I.; Košec, M.; Brindza, J.; Grygorieva, O.; Tokár, M. Green Barley as an Ingredient in Pasta: Antioxidant Activity and Sensory Characteristics Evaluation. Contemp. Agric. 2018, 67, 81-86. [CrossRef]

72. Palavecino, P.M.; Ribotta, P.D.; Leóna, A.E.; Bustosa, M.C. Gluten-free sorghum pasta: Starch digestibility and antioxidant capacity compared with commercial products. J. Sci. Food Agric. 2019, 99, 1351-1357. [CrossRef] [PubMed]

73. Kuhnen, S.; Moacyr, J.R.; Mayer, J.K.; Navarro, B.B.; Trevisan, R.; Honorato, L.A.; Maraschin, M.; Pinheiro Machado Filho, L.C. Phenolic content and ferric reducing-Antioxidant power of cow's milk produced in different pasture-based production systems in southern Brazil. J. Food Sci. Agric. 2014, 94, 3110-3117. [CrossRef]

74. Manzi, P.; Durazzo, A. Antioxidant properties of industrial heat-treated milk. J. Food Measur. Charact. 2017, 11, 1690-1698. [CrossRef] 
75. Mattera, M.; Durazzo, A.; Nicoli, S.; Di Costanzo, M.G.; Manzi, P. Chemical, nutritional, physical and antioxidant properties of Pecorino d'abruzzo cheese. Ital. J. Food Sci. 2016, 28, 579-597.

76. Yilmaz-Ersan, L.; Ozcan, T.; Akpinar-Bayizit, A.; Sahin, S. Comparison of antioxidant capacity of cow and ewe milk kefirs. J. Dairy Sci. 2018, 101, 3788-3798. [CrossRef]

77. Calligaris, S.; Manzocco, L.; Anese, M.; Nicoli, M.C. Effect of heat-treatment on the antioxidant and and pro-oxidant activity of milk. Int. Dairy J. 2004, 14, 421-427. [CrossRef]

78. Zulueta, A.; Maurizi, A.; Frigola, A.; Esteve, M.J.; Coli, R.; Burini, G. Antioxidant capacity of cow milk, whey and deproteinized milk. Int. Dairy J. 2009, 19, 380-385. [CrossRef]

79. Cortés Yáñez, D.A.; Gagneten, M.; Leiva, G.E.; Male, L.S. Antioxidant activity developed at the different stages of Maillard reaction with milk proteins. LWT 2018, 89, 344-349. [CrossRef]

80. Bars-Cortina, D.; Macià, A.; Iglesias, I.; Romero, M.P.; Motilva, M.J. Phytochemical profiles of new red-fleshed apple varieties compared with traditional and new white-fleshed varieties. J. Agric. Food Chem. 2017, 65, 1684-1696. [CrossRef] [PubMed]

81. Kumar, P.; Sethi, S.; Sharma, R.R.; Singh, S.; Saha, S.; Sharma, V.K.; Verma, M.K.; Sharma, S.K. Nutritional characterization of apple as a function of genotype. J. Food Sci. Technol. 2018, 55, 2729-2738. [CrossRef] [PubMed]

82. Phenol-Explorer-Database on Polyphenol Content in Foods. Available online: http://phenol-explorer.eu/ (accessed on 15 January 2019).

83. Leclercq, C.; Arcella, D.; Piccinelli, R.; Sette, S.; Le Donne, C.; Turrini, A.; INRAN-SCAI 2005-06 Study Group. The Italian National Food Consumption Survey INRAN-SCAI 2005-06: Main results in terms of food consumption. Public Health Nutr. 2009, 12, 2504-2532. [CrossRef] [PubMed]

84. Finglas, P.M.; Berry, R.; Astley, S. Assessing and improving the quality of food composition databases for nutrition and health applications in Europe: The contribution of EuroFIR. Adv. Nutr. 2014, 5, 608-614. [CrossRef]

85. Durazzo, A.; Kiefer, J.; Lucarini, M.; Marconi, S.; Lisciani, S.; Camilli, E.; Gambelli, L.; Gabrielli, P.; Aguzzi, A.; Finotti, E.; et al. An innovative and integrated food research approach: Spectroscopy applications to milk and a case study of a milk-based dishes. Braz. J. Anal. Chem. 2018, 5, 12-27. [CrossRef]

86. Durazzo, A.; Kiefer, J.; Lucarini, M.; Camilli, C.; Marconi, S.; Gabrielli, P.; Aguzzi, A.; Gambelli, L.; Lisciani, S.; Marletta, L. Qualitative Analysis of Traditional Italian Dishes: FTIR Approach. Sustainability 2018, 10, 4112. [CrossRef]

87. Tabart, J.; Kevers, C.; Pincemail, J.; Defraigne, J.O.; Dommes, J. Comparative antioxidant capacities of phenolic compounds measured by various tests. Food Chem. 2009, 113, 1226-1233. [CrossRef]

88. Apak, R.; Özyürek, M.; Güçlü, K.; Çapanoglu, E. Antioxidant activity/capacity measurement. 1. Classification, physicochemical principles, mechanisms, and electron transfer (ET)-based assays. J. Agric. Food Chem. 2016, 64, 997-1027. [CrossRef] [PubMed]

89. Apak, R.; Özyürek, M.; Güçlü, K.; Çapanoglu, E. Antioxidant Activity/Capacity Measurement. 2. Hydrogen Atom Transfer (HAT)-Based, Mixed-Mode (Electron Transfer (ET)/HAT), and Lipid Peroxidation Assays. J. Agric. Food Chem. 2016, 64, 1028-1045. [CrossRef]

90. Apak, A.; Capanoglu, E.; Shahidi, F. Measurement of Antioxidant Activity and Capacity: Recent Trends and Applications; Wiley: New York, NY, USA, 2018; ISBN 978-1-119-13535-7.

91. Leopoldini, M.; Russo, N.; Toscano, M. The molecular basis of working mechanism of natural polyphenolic antioxidants. Food Chem. 2011, 125, 288-306. [CrossRef]

92. Schlesier, K.; Harwat, M.; Bohm, V.; Bitsch, R. Assessment of antioxidant activity by using different in vitro methods. Free Radic. Res. 2002, 36, 177-187. [CrossRef] [PubMed]

93. Prior, R.L.; Wu, X.; Schaich, K. Standardized methods for the determination of antioxidant capacity and phenolics in foods and dietary supplements. J. Agric. Food Chem. 2005, 53, 4290-4302. [CrossRef]

94. Benzie, I.F.F.; Strain, J.J. The ferric reducing ability of plasma (FRAP) as a measure of "antioxidant power": The assay. Anal. Biochem. 1996, 239, 70-76. [CrossRef]

95. Pulido, R.; Bravo, L.; Saura-Calixto, F. Antioxidant activity of dietary polyphenols as determined by a modified ferric reducing/antioxidant power assay. J. Agric. Food Chem. 2000, 48, 3396-3402. [CrossRef] [PubMed]

96. Singleton, V.L.; Orthofer, R.; Lamuela-Raventos, R.M. Analysis of total phenols and other oxidation substrates and antioxidants by means of Folin-Ciocalteu reagent. Methods Enzymol. 1999, 299, 152-178. 
97. Nascimento-Souza, M.A.; Paiva, P.G.; Martino, H.S.D.; Ribeiro, A.Q. Dietary total antioxidant capacity as a tool in health outcomes in middle-aged and older adults: A systematic review. Crit. Rev. Food Sci. Nutr. 2018, 58, 905-912. [CrossRef] [PubMed]

98. Parohan, M.; Anjom-Shoae, J.; Nasiri, M.; Khodadost, M.; Khatibi, S.R.; Sadeghi, O. Dietary total antioxidant capacity and mortality from all causes, cardiovascular disease and cancer: A systematic review and dose-response meta-analysis of prospective cohort studies. Eur. J. Nutr. 2019. [CrossRef]

Sample Availability: Samples of the compounds are available from the authors.

(C) 2019 by the authors. Licensee MDPI, Basel, Switzerland. This article is an open access article distributed under the terms and conditions of the Creative Commons Attribution (CC BY) license (http://creativecommons.org/licenses/by/4.0/). 